\title{
A PRESENÇA DO CORÃO NO CANCIONERO DE MIGUEL DE UNAMUNO (I).
}

\author{
JORGE CESAR MOTA \\ Do Departamento de História da Faculdade de Filo- \\ sofia, Letras e Ciências Humanas da Universidade de \\ São Paulo.
}

\section{INTRODUÇÃO.}

O árabe, e, por conseguinte, o Corão, que é o texto clássico fundamental para o seu estudo, ocupam lugar de importância nos currículos universitários espanhóis. A primeira cátedra de árabe em Madrid só no comêço do sécu'o XIX se instalou (1), porém, já desde - século $\mathrm{X}$ os estudiosos se interessavam pela língua dos invasores muçulmanos que tanta influência exerceram sôbre a cultura européia, como se sabe. Basta lembrar o cenóbio de Ripoli, de onde saiu o monge Gerberto para se tornar Papa Silvestre II, o qual foi, provàvelmente, o primeiro, na Europa, a dar atenção à, já então, volumosa obra científica e filosófica islâmica. Ao mesmo mosteiro pertencia o cata!ão Llobet, famoso por suas traduções de textos arábicos. Lembre-se também a Escola de Tradutores, do século XII, cuja fama atraiu a Toledo tantos estrangeiros famosos, e de onde havia de sair a primeira versão latina do Corão, feita por Roberto de Chester sob a direção do abade de Cluny, Pedro o venerável, e a segunda, no século XIII, pelo cônego Marcos de Toledo. E ainda-a notável figura do filósofo e místico Raimundo Lúlio, que Ribera chamou "el sufi cristiano", o qual estudou profundamente o livro sagrado do maometismo na língua original. Foi, aliás, no seu tempo que, por ordem de

(1). - Pascual Gayangos (1809-1897) foi o primeiro catedrático. Seguiuse-lhe don Francisco Cordera (1836-1917), seu discípulo, que veio a ser o professor de Unamuno, conforme o próprio testemunho dêste no prefácio à segunda edição da Vida de Don Quixote y Sancho (VDQS IV 69). Segtondo Soledad Gibcrt (Diccionario de Historia de España, tomo I, $236 \mathrm{~b}$ ), foi Cordera o iniciador da moderna escola de arabistas espanhóis. 
Afonso X, o Sábio (2), se traduziu em vernáculo o Corão, embora do latim. Não se esqueça que, já no século XVIII, ao continuar a obra de seu pai Filipe V fundador da Biblioteca Real (depois Nacional) de Madrid, Carlos III estabeleceu como condição de promoção de funcionários o conhecimento da língua árabe, tal a riqueza do acervo da Biblioteca nesse idioma.

Não se poderia conceber que a língua de um povo que, por oito séculos, permaneceu na Espanha e tão profundas marcas deixou na arte, na arquitetura, na língua, na literatura, nos costumes, na cultura, enfim, de sua gente, pudesse ser esquecida dos responsáveis pela educação da juventude espanhola.

Nada há que estranhar, portanto, que o jovem Unamuno tivesse seguido, na Faculdade de Filosofia e Letras da Universidade Central de Madrid, o curso de árabe simultâneamente com os de História, Língua e Literatura Grega e Latina, História Crítica de Espanha, Metafísica, e ainda de Sânscrito e Hebraico (3). Vale a pena recordar, a propósito, o prólogo à edição da Vida de Don Quixote y Sancho, onde, entre sério e irônico, alude a seu conhecimento do árabe, ao responder a uma consulta de seu tradutor para o inglês:

“... aunque he olvidado todo el poquísimo arabe que me enseñó el señor Cordera en la Universidad de Madrid - y me dió el premio en la asignatura! -, lo leo de corrida y en él he visto que en el pasaje a que aludía el profesor Earle fué Cervantes él que leyó mal y que mi interpretación, y no la suya, es la fiel" (4).

Ao longo da obra de Unanumo, não é fácil ignorar seu interêsse pela cultura islâmica. As razões dêsse interêsse são múltiplas. Por um lado, sem dúvida, a própia e indissolúvel relação do islamismo com a história da Espanha. Aí estão as obras de Menendez Pidal e de Américo Castro para demonstrá-lo, se não bastassem os próprios fatos que o estudioso das coisas ibéricas descobre por si. Podem dissentir os críticos sôbre um grande número de pormenores, mas ninguém pode ignorar a presença oito vêzes secular dos seguidores de Maomé na Península.

Já na famosa correspondência com Ganivet, havia D. Miguel discutido o problema, sem esconder, naquela altura, seu pessimismo sôbre os resultados da presença árabe em sua Pátria.

(2). - "The great apostol of Muslim learning in Christian Spain", no sentir de J. B. Trend, The Legacy of Islanz, Oxford University Press, 1931, pág. 31.

(3). - Cf. Yvonne Turini, Miguel de Unamuno Universitaire, p. 14.

(4). - VDQS IV 69. 
"De los árabes - escreve Unamuno - no quiero decir nada, les profeso una profunda antipatía, apenas creo en eso que llaman civilización arábiga y considero su paso por Epaña como la mayor calamidad que hemos padecido" (5).

Assim pensava em 1898, o ano crítico da história moderna de Espanha. Quatro anos mais tarde, nos Juegos Florales de Cartagena, em 8 de agôsto de 1902, ao comentar a situação em sua pátria, que era tratada como "cuestión religiosa", na realidade "cuestión político-eclesiastica", refere-se Unamuno à

"maridaje del Evangélio galileo y de Derecho Romano en que aquél se nos oscurece y enturbia",

e compara a atmosfera espiritual de seu tempo com a do islamismo primitivo, nestes têrmos:

"Bajo el fetichismo y la superstición populares de nuestros campos, como bajo el fetichismo y superstición arábigos en tiempos de Mahoma..." (6).

Apesar dêsse ponto de vista negativo por que encarava o íntimo da religiosidade muçulmana, reconhecia $D$. Miguel valores inegáveis no islamismo. E' assim que êsse mesmo crítico impiedoso, de quem disse Ganivet na correspondência referida

"usted profesa antipatía a los árabes, y yo les tengo mucho afecto, sin poderlo remediar" (7),

escreveria:

"Ya de antiguo se distinguieron los hispanos a la vez que por su indisciplina, por su apego al cabecilla, extremado al punto de la costumbre dicha del agermanamiento nuestro. Buscóse, pues, unidad, y se buscó en la religión. La desgracia fué que no fuese sobre un credo amplio y sobrio, austero y sencillo, algo así como un Islam cristiano, bajo su concepto, y mejor que concepto sentimiento de la Divinidad, que por su poca comprensión y mucha sencillez le permitiera una

(5). - PDE IV 966. Essa posição de Unamuno tão extrema e negativa, não é contraditória com a compreensão da importante herança islâmica na Espanha. Estou certo de que êle subscreveria páginas como, por exemplo, as de Fernando Soinz, em História de la Cultura Española, Edit. Nova, Buenos Aires, 1957, págs. 135-138.
(6). - E y E IV 1082 .

(7). - PDE IV 969. 
extensión vasta, bajo el Dios insondable y cordial de los abismos de los cielos, de las tierras y de los espíritus, que así impuso unidad el musulmán, y fué, sin embargo, tolerante con los demás creencias".

\section{E acrescenta:}

"En vez del "acto de notícia confusa, amorosa, pacífica y sosegada", para decirlo con decir de nuestro San Juan de la Cruz', nos dió el latino un tejido de dogmas, fórmulas, rúbricas y prescripciones, muy lejano de la libertad y de la sencillez evangélicas, una trama codificada en que el espiritu se ahogaba". "Y asi, concluída la Reconquista, acabó de romanizarnos la invasión cluniacense, se desterró a judíos y moriscos, no en nombre de Dios, que nos era común, sino en nombre de una teología peor o mejor interpretada y encubridora de bajas pasiones, y la Inquisición brotó al cabo" (8).

Desta havia de falar D. Miguel freqüentemente e algumas vêzes relacionando-a com o problema arábico. A propósito da unidade nacional como objetivo que se conseguiu não com amor, mas com ódio, o reitor de Salamanca, numa famosa conferência pronunciada no Teatro Novedades, de Barcelona, em 1906, afirma que foi assim que se deu a união entre o Trono e o Altar,

"fatal al Trono, fatalisimo al Altar".

Depois de algumas citações de Las Mocedades del Cid, de Verdaguer e de Hernando de Acuña, diz:

"Se hizo la unidad nacional sobre la base de la unidad religiosa, y para hacer la unidad religiosa se impuso la Inquisición, y la Inquisición nos ha traído a la larga el régimen de mentira en que vivimos" (9).

Essa unidade religiosa surgiu num clima diametralmente oposto ao que lhe seria próprio:

"Castilla fué un país unitario. Tuvo que serlo. Se encontró frente a los mahometanos que invadieron la Península; empezó a luchar con ellos; la unión se hizo frente al infiel: unió a las gentes, más que el amor mutuo, un odio a los otros" (10).

Já havia sublinhado Troeltsch, citado pelo próprio Unamuno, a salutar influência da cultura cristã, ao lado da grega e da persa, sô-

(8). - E y E' IV 1084-5.

(9). - CD VII 742 .

(10). - Ibid. 741 . 
bre o evoluir do Islão (11), mas é necessário não esquecer o papel do Cristianismo espanhol nesse processo. Basta consultar, na história da filosofia medieval, os escritos dos pensadores arábio-espanhóis .

Da impossibilidade de se atentar para a fôrça da presença da religião islâmica nos acontecimentos históricos da Espanha fala-nos o eloqüente epitáfio dos reis católicos:

"Mahometice secte prestratores

et heretice pervicacie extintores

Fernandus Aragonum et Helisabetha Castelle

Catholici apellati

marmoreo clauduntur hoc tumulo".

Aí está, como bem adverte Américo Castro, um sinal do

"sentido dado pelos espanhóis à tenaz luta de oito séculos contra o Islão, coroada felizmente para os cristãos com a conquista de Granada em 2 de janeiro de 1492" (12).

Talvez estivessem os episódios da Guerra de Granada na mente de Unamuno ao referir-se ao entardecer de Rabad al Bayazin

"Aquel sereno atardecer del Albaicín, polvo de oro de sol andaluz...".

Ali onde se decidiu, pela guerra sangrenta e terrível, unidade da nação espanhola, sentiu o poeta que Granada o sonhava

“Como a Fray Luis y'al Padre Suárez les soñó..." (13).

A cada passo, na leitura do Cancionero, esbarramos com êssë tema do interêsse histórico.

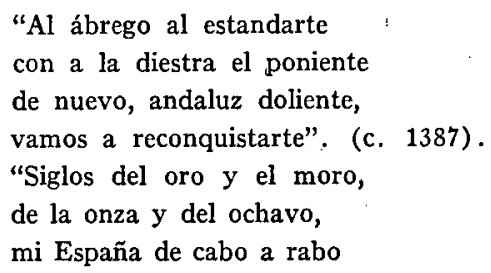

"Al ábrego al estandarte con a la diestra el poniente de nuevo, andaluz doliente, vamos a reconquistarte". (c. 1387). "Siglos del oro y el moro, de la onza y del ochavo, mi España de cabo a rabo

(11). - STV XVI 240 (Citando Systematische Christliche Religion, em Die Kultur der Gegenwart). Veja-se a seguir a nota 35 sôbre a opinião de Ortega y Gasset.

(12). - Américo Castro, Origen, ser y existir de los españoles, Ser y Tiempo, Taurus, Madrid, 1959 , pág. 3 .

(13). - C XV c. 560. 
reyertas formaron coro.

Soñó mi España su vida, vivió mi España su ensueño, cifró mi España su empeño en no acabar la partida".

E logo acrescenta, porque Espanha sempre a trazia entranhada em si, porque "le dolia España",

"Y hoy que ni España ya ha sido

y que comienza otra España

va a renacer en mi entraña

la que España da al olvido". (c. 1169).

A herança cultural do espanhol contém (ao lado do Cristianismo, da Palavra do Evangelho, o contributo islâmico, e D. Miguel, que não se contentava com as aparências, o sentia. Mesmo quando não estava no seu plano tratar do assunto podia deixá-lo transparecer como, ao que me parece, fêz na canção no 255 , escrita em 4 de julho de 1928. Na que se lhe segue, dirá, confirmando o que acima sugiro, que

"El alma es un palimpsesto". (c. 256).

$\mathrm{Na}$ outra, havia escrito que foi por Cristo, o Verbo divino pré-encarnado, que o Universo ganhou sua "alma". Reminiscência de São João e do Gênesis, nos primeiros versículos de ambos os livros bíblicos.

\footnotetext{
"Por la Niñez balbuciente

que es Palabra creadora

entró al Universo el alma;

por el Niño de la Bola".
}

Com a imagem do "Niño de la Bola", tão assídua nos núcleos católicos, acudiu ao espírito do poeta tudo quanto à criança se associa e, portanto, a delícia das estórias, dos contos encantados da infância, e, logo,

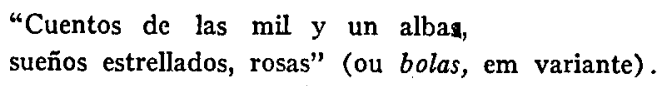

Vejo aí duas superfícies do palimpsesto. escreve:

Outras transparecem noutros poemas. Ainda no Cancionero, 


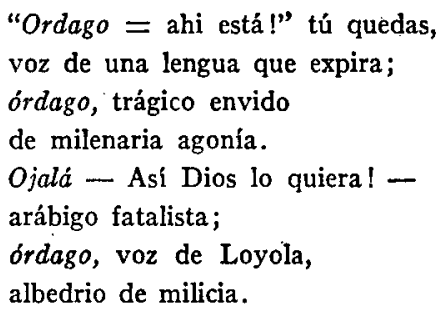

Chama a êsses estratos, raças:

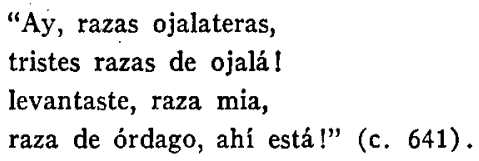

Como compreender Espanha se se separarem os elementos tão diversos que a constituiram? Rafael Altamira, um dos que, ao tempo em que Ganivet e Unamuno meditavam sôbre o problema que ambos magistralmente, cada um a seu modo, discutiriam, respectivamente, no Idearium Español e nos ensaios En torno al Casticismo, citou uma frase de Oscar Wi'de muito apropriada:

"El pasado es lo que nos forma. Es lo único que nos puede servir para juzgar" (14).

Nessa base histórica não se pode menosprezar a ação e atitudes dos filhos do Corão. Por tôda parte, em Castela ou na fronteira pirenaica, o grande pensador basco-salmantino a reconhece.

"Siempre que contemplo - escreve êle nos ensaios acima referidos - la llanura castellana recuerdo dos cuadros. Es el uno un campo escueto, seco y caliente, bajo un cielo intenso, en que llena largo espacio inmensa muchedumbre de moros arrodillados, con las espingardas en el suelo, hundidas las cabezas entre las manos apoyadas en tierra, y al frente de ellos, de pie, un caudillo tostado con los brazos tensos al azul infinito y la vista perdida en él, como diciendo: "Sólo Dios és Dios!" En el otro cuadro se presentaban, en el inmenso páramo muerto, a la luz derretida del crepúsculo, un cardo quebrando la imponente monotonía, en el primer término, y en lontananza, las siluetas de Don Quijote y Sancho sobre el cielo agonizante.

(14). - Rafael Altamira, Psicología del Pueblo Español, Barcelona, 2.a edição, s. d., pág. 205. 
"Sólo Dios és Dios, la vida és sueño y que el sol no se ponga em mis domínios", se recuerda contemplando estas llanuras" (15).

\section{Andando por Vizcaya}

de Oñate a Aitagorri, com os olhos postos ao longe "o bêrço de Zumalacárregui e onde seus restos mortais aguardam a batalha derradeira",

\section{Unamuno pensa nos pastores que}

"cerran el paso en Roncesvalles a Carlomagno, los que derrotaron a Roldán..." "¿Por qué? En el fondo por luchar" (16).

"Oigo subir de lo hondo del abismo verde en que penan los hombres, un ladrido, y me acuerdo del ladrido del perro de Ibañeta, el que anunció al pastor de Altobiscar la presencia de las huestes de Carlomagno. Y el pastor contó los guerreros franceses, uno, dos, tres, cuatro..., y sonó la trompa de Roldán, y rodaron peñascos desde las crestas, y pereció el ejécito y volvió el pastor a contarlos: mil, cien, veinte, cuatro, tres, dos, uno,j ni uno! $\mathrm{Y}$ siglos después, desde estas mismas alturas en que yo soñaba la Historia y la Leyenda, desde este mismo macizo de Aitzgorri avizoró el zorro Zumalacárregui las huestes de Napoleón para caer sobre ellas' (17).

E termina D. Miguei o artigo, escrito em Bilbao em 1909, com estas significativas palavras:

"Ya que tanto os sermoneo desde mi rincón académico de Salamanca, no os parecerá mal qúe alguna vez dé vuelta a las sugestiones de estas libres escapadas por los valles y cumbres de mi tierra. ¿Quién sabe si dentro de este rector universitário enjaulado en Salamanca, dentro de este hosco predicador, no se revuelve prisionero el libre zorro cazador? Lo que ellos, mis nobles antepasados, hacían con la honda o el fusil, ¿no lo hago yo con la pluma? Eso que IIaman mis paradojas; ¿que son?; Que me echen, que me echen encima las huestes de Carlomagno o las de Napoleón! También yo tengo mi fragoso Altobiscar, mi Aitzgorri pedregoso, mis crestas de águilas, mis madrigueras de zorros" (18).

\section{dirá:}

Vinte anos mais tarde, num poeminho de brincar com os erres,

$$
\begin{aligned}
& \text { (15). - TC III } 212 . \\
& \text { (16). - TPE I 520. } \\
& \text { (17). - Ibid. 521: } \\
& \text { (18). - Ibid. 522-3. }
\end{aligned}
$$


"De Roldán, roble recio, el arresto

¡Roncesvalles! rompió raza arrecha

y resuenan los rojos romances

enterrando la regia leyenda" (19).

"Leyenda', que era sua também, como o diz bem no comêço do Cancionero, respirando o ar de Vizcaya sem poder por pé em sua terra,

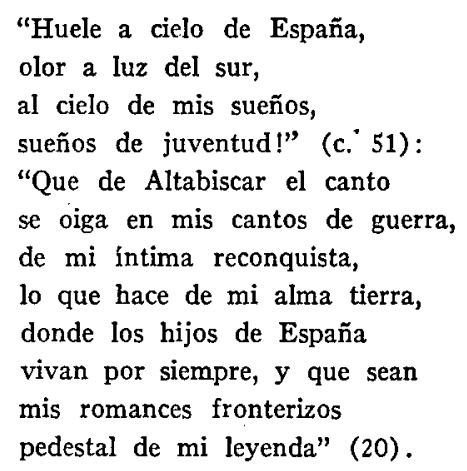

Mas, sugeri que outras razões devia ter Unamuno para interessar-se pela cultura islâmica além da compreensão do alcance de sua presença na estrutura da civilização espanhola, e mesmo hispânica, como um de seus mais importantes estratos. E, entre essas outras razões, estava, certamente, o próprio Islão como tal. A curiosidade de Unamuno, seu anseio de conhecimento eram insaciáveis, sobretudo quando se tratava de temas tão ìntimamente ligados à sua terra e à sua gente, como era o caso do Islamismo.

Em minha última visita à Biblioteca de D. Miguel, na Casa Rectoral de Salamanca, tive nas mãos uma obra publicada no mesmo ano de sua morte e, portanto, um dos últimos livros lido e anotado pelo incansável pesquisador. Trata-se do El Renascimiento del Islam, de A. Mez, traduzido do alemão por Salvador Vila, publicado em Madrid em 1936. Muitas são as marcas de D. Miguel, como, por exemplo, às págs. $257,348,230,231,259,260$. Não o tivesse a morte levado naquele ano, e teríamos hoje, provàvelmente, mais um de

(19). - C XV c. 674

(20). - C XV c. 84 . 
seus inteligentes comentários, e, justamente sôbre tema de que êle especificamente não tratara nunca.

E' certo que em diversas oportunidades fêz D. Miguel referências à questão islâmica, porém, simplesmente de passagem. Não é objeto dêste trabalho tratar do Islão, mas tão sòmente da presença, no Cancionero de Unamuno, do livro sagrado da mais nova das grandes religiões, a qual é hoje, uma das mais importantes, não só em número de adeptos, mas também quanto à influência que exerce em muitas culturas do mundo moderno. Limitar-me-ei, pois, a citar alguns dos textos em que o Islão é, ao menos, mencionado, ou mesmo subentendido.

Importa, porém, referir a curiosa circunstância de que, ao tempo em que os poemas do Cancionero foram compostos, isto é, ao tempo da "fronteira", grande era o interêsse pelos assuntos islâmicos em tôda a Europa. No lugar próprio, mencionarei as obras relativas especificamente ao Corão. Por ora, apenas desejo lembrar meia dúzia das de maior importância aparecidas entre 1927 e 1929.

Em Espanha, o grande especialista Miguel Asin Palácios, da Real Academia Española, que tanta discussão suscitara com seu famoso "La Escatologia Musulmana en la Divina Comedia", publicado em 1919, produzira em 1927 uma obra em 5 volumes intitulada "Aben hazam de ICordoba y su historia crítica de las ideas religiosas", Madrid. Em 1926, T. Andrae, da Universidade de Upsala, publica Der Ursprung Islams und das Christentum e em 1928 Die Person Muhammeds. Em 1926 aparecera o Koranische Untersuchungen de J. Horovitz, e o The origin of Islam in its Christian Environment, de Richard Bell. Em 1929, em Florença, publica-se a obra de B. Ducati Vita de Maometto, e em França o Sur quelques noms d'Allah dans le Coran, de Gaudefroy-Demombynes .

A despeito de fato de estar Unamuno numa pequena cidade de fronteira, longe dos grandes centros e das grandes livrarias, é fora de dúvida que não passava despercebida ao famoso exilado a edição de obra nova alguma em qualquer ponto do mundo, graças não apenas ao contacto ininterrupto com intelectuais, com quem se correspondia e que freqüentemente o visitavam, mas, em particular, mediante a assídua e minuciosa leitura dos catálogos e das listas editoriais habitualmente colocadas no final da maioria das obras que lia.

No Cancionero, não há muita coisa sôbre o Islão em particular. Vejamos alguns exemplos.

Um texto bíb ico, que o poeta põe em epígrafe, Gal. 4.24-31, sugere-lhe uma de suas canções:

(21). - Cite-se ainda importante artigo de G. Sanchez Albornoz, España y el Islam, na "Revista de Occidente", VII, n. 70. 


\begin{abstract}
"Agarenos, agarenos
hijos de la pobre esclava,

hijos del desierto ardiente,

os llega vuestro mañana!

Brille vuestro alfanje corvo

sobre los hijos de Sara

y el solo Dios que es Dios solo

os dé maná de esperanzas.

En vuestro cielo sin nubes

no hay ensueños ni fantasmas,

tocáis por sueño la tierra

que os sirve de almohada.

Agarenos, agarenos,

Llega ya vuestra batalla;

Alá es grande: y aun más grande

que el mismo Alá es la nada" (22).
\end{abstract}

Outra interessante composição, feita quase dois anos mais tarde, é a que traz o número 1386 , e que começa:
"Se asentó la caravana
aburrida del camino;
se ha olvidado del mañana,
tienen pan y tienen vino".

Creio que, nesta canção, Unamuno reflete uma particular tradição islâmica sôbre a morte de Maomé:
"En un rincón del desierto
enterraron el profeta;
con su profecia muerto
ya está al fin su boca quieta.
Como sepultura el carro
desde el que dió su verdad...".

No poema seguinte, composto no mesmo dia, salta D. Miguel da paisagem da ardente Arábia para a Andaluzia:

(22). - C XV c. 71. Este poema está a pedir um comentário. Mas qual dos de Unamuno o não pede? A associação do texto de São Paulo ao fenômeno islâmico da forma como o fêz D. Miguel; a palavra mañana entre aspas, como em outros lugarcs ocorre em relação com. Maomé; a frase "el solo Dios que es Dios solo"; a referência ao maná num contexto arábico e não judeu; o terceiro quarteto, em seu paralelismo em tradições bíblicas; e, finalmente, a afirmação, nos últimos dois versos de que o nada é maior que o próprio Alá. Nenhuma possibilidade existe de caior aqui na tentação de tal comentário, em face da tarefa mais urgente que me impus. 
"Al ábrego al estandarte con a la diestra el poniente de nuevo, andaluz doliente".

porque não tem mais as costas voltadas para a África de onde vieram os muçulmanos, porque agora é a "reconquista"

"vamos a reconquistarte".

Aqui também, como no anterior poema, sobejam problemas a acicatar-nos a um comentário, sobretudo no que concerne ao simbolismo patente. Mas... repito o que está na nota 22 (23).

Para finalizar esta rápida série de poemas alusivos ao islamismo, lembremos a canção 555

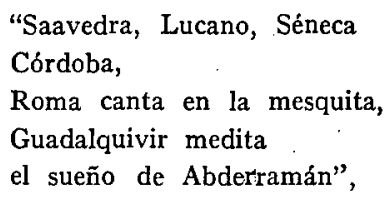

onde, segundo nota do próprio autor (24), o verso "Roma canta en la mezquita" se refere ao templo cristão construído dentro da mesquita muçulmana no século XVI.

E dessa forma nos leva a imaginação a um terceiro fator atuante no espírito de Unamuno ao interessar-se pela cultura islâmica. Não esteve presente nele apenas a relação indissolúvel entre o islamismo e a história da Espanha, nem também ainda o próprio Islão em si, porém, como fàciimente se percebe, aliás, em qualquer livro de $\mathrm{D}$. Miguel, o seu interêsse religioso. Sirva-nos de símbolo essa Igreja cordobense edificada no interior de uma mesquita, e o povo católico entoando nela as litanias ao som do órgão, em lugar do Allahu akbar

\footnotetext{
(23). - Seria preciso também aludir ao n.o 1294, com seu

"Ceñudo Cristo martillo

de los ojos de azabache..."

aquêle

"Cristo del Cid, cuatro clavos,

tú que nos has hecho esclavos,

Cristo, de la reconquista".

que nos recordaria o cristianismo de uma condição particular a que se

"...dan mil sonoros nombres

de civilización".

cuja cruz "protege mercancía" e cujo Deus é

"un Dios ateo,

un Dios de las ideas..." (PS XIV 794-800)

(24). - C XV p. 950.
} 
e dos surates corânicos do ritual maometanó. Noutros lugares o contrário tinha acontecido, em Constantinopla, com a Igreja de Santa Sofia transformada em mesquita, em Atenas, onde o próprio Partenão se adaptou ao culto de Alá...

Não creio que foi simplesmente, ao sabor da rima generatrix, por acaso, que Unamuno construiu desta maneira a canção 511

\author{
"El Cid, Loyola, Pizarro, \\ Santa Teresa, la Armada, \\ oro, sudor, sangre, barro, \\ cielo, sueño, polvo... nada".
}

Nessa admirável síntese, marcam momentos significativos e decisivos quatro personagens e um fato histórico, êste criação de homens fanatizados por uma idéia, como os outros. Das personagens, duas são heróis guerreiros e conquistadores e as outras figuras da religião. Os nomes sucedem-se alternando-se as naturezas: herói-religião-herói-religião. O fenômeno - a Armada Invencível - leva-nos a imaginação ao fato histórico, ao acontecimento, à tragédia. Esse fato histórico, que foi a destruição da "Invencible" em julho de 1588, com seus 130 navios e 29.000 homens, entre marinheiros, remeiros e homens de guerra, traz-nos à lembrança nomes famoșos: Álvaro de Bazán, Marquez de Santa Cruz, seu comandante, que não chegou a combater, tendo morrido antes da frota sair de Lisboa;'seu substituto, o jovem don Alonzo Pérez de Guzmán, cuja incompetência foi um dos fatôres para o desastre; acima dê'es, o rei Filipe II. Do outro lado, a Rainha Isabel I, Drake, Lord Howard. Os nomes do Cid, Loyola, Pizarro e Santa Tereza, por seu turno, lembram-nos fatos históricos muito conhecidos. E atrás de todos êsses fatos e êsses nomes subsiste a religião. O ouro, o suor, o sangue, eram barro; o céu, o sonho eram só pó ... nada!

Por que nada?

Não cabe discutir aqui essa apaixonante questão, levantada de maneira tão singela nessa cuarteta. Contudo, ao citá-la apontando algumas das ricas sugestões que nela $D$. Miguel nos faz, nada mais desejo senão mostrar a constância da presença do problema religioso no âmago da História de Espanha como a via Unamuno. Todos os fatos a que aludem os elementos do pequeno poema são, em și, religiosos ou tiveram motivação religiosa. Não só os portuguêses, com suas conquistas na América

"a fé e o império foram dilatando", 
como tão bem salientou o vate dos Lusíadas. Os espanhóis também (25).

Para finalizar esta digressão, direi apenas que todos os fatos históricos implícitos nos cinco têrmos da estrofe que abrangem pràticamente tôda a história da Espanha, devem sua realidade a Maomé.

Cid, para não aludir mais de que ao nome, outra coisa não significa senão señor mio... em árabe: Say Yidi (26). Loyola, Pizarro e a Invencible Armada, todos são decorrência das lutas religiosas provocadas pela Reforma Protestante. Loyola foi verdadeira replica de Lutero, e sua Companhia réplica da Reforma. Estudou na Universidade de Alcalá que fôra fundada pelo Cardeal Ximenes de Kisneros para ser o centro da reforma espanhola. Pizarro representa, no poema, a expansão do Catolicismo fora da Europa que, de algum modo foi feita pelos povos fiéis a Róma, Portugal e Espanha, para compensar a Igreja de suas tremendas perdas no Continente europeu. A Armada Invencível foi fruto das circunstâncias religiosas na Inglaterra, onde católicos e protestantes disputavam o poder e na Espanha, cujo rei

(25). - Este seria, de fato, um veio merecedor de atenção. Dentre os autores que o têm explorado, basta mencionar o erudito historiador Américo Castro em sua famosa obra España en su Historia, que freqüentemente cito neste trabalho. Creio de extrema importância a obra de Américo Castro sobretudo porque sublinha a circunstância de a religiosidade espanhola não se dever tão sòmente à presença do cristianismo, mas igualmente ao islamismo. Do plonto de vista histórico, já afi mou Henri Pirenne que "sem Maomé não existiria Carlos Magno". Creio que se pode inferir da pesquisa realizada por Castro que, sem o islamismo na península, não teria perdurado e, em certo sentido, existido Santiago de Compostela. Mas deixarei falar o próprio Américo Castro: "La religión española, por conseguinte, está basada en un catolicismo muy distinto del de Roma y Francia - para no hablar del norte-americano. Es una forma de creencia característica de España, sólo inteligible dentro de la peculiar "situación vital" de su história. La religión española - como su lengua, sus instituciones, su escasa capacidad para la ciencia objetiva, su desbordo expresivo y su personalismo integral - ha de ser ref:rida a los 900 años de entrelace cristiano-islámico" (ob. cit., pág. 99). "De no haber sido España sumergida por el Islam, el culto a Santiago de Galicia no hubiera prosperado. Mas la angustia de los siglos VIII y IX fortaleció su fé en un Santiago Hermano del Señor..." (ib., p. 108). "Los cristianos existieron demasiados siglos teniendo como limite de su paisaje moral el horizonte del Islam, para que éste dejara de intervenir en los usos de la conciencia, a la larga, tan subconscientes y recónditos, que ningun signo exterior delata que origenes islámicos" (ib., p. 215).

. (26). - Ver R. Menendez Pidal, España y su Historia, Tomo I p. 389 e Americo Castro, España en su Historia, pág. 255. 
católico, Filipe II intentou vencer pela fôrça o poderio da protestante Isabel. De Santa Tereza de Ávila não se pode dizer o mesmo que se disse dos outros, em relação ao Protestantismo, porém, não será possível negar-se que ela é a mais alta representante da mística católica romana e que sua consagração decorreu, como ela mesma conta na sua 'Vida, da forma como reagiu à proibição da leitura das Escrituras em vernáculo, visto como, ignorando o latim, passou a depender diretamente das visões de seu Senhor. E desnecessário lembrar que a proibição da leitura da Bíb'ia, na época, em vernáculo, visava impedir a expansão do Protestantismo na Espanha.

Ora, pode parecer estranho que venha insistindo em relacionar os elementos do quarteto do Cancionero com o fenômeno protestante quando o interêsse do autor dêste trabalho parecia estar no islamismo. Aliás, não seria difícil encontrar relações diretas ou indiretas, de cada um daqueles elementos com a religião de Maomé. A razão é simples: o próprio Protestantismo foi salvo na Europa pelo islamismo... Transcrevo um trecho de conhecida autoridade, o anglicano Stephen Neill. Escreve êle:

"En 1526, la victoire des Turcs à Mohacs plaça la Hongrie sous une menace d'invasion. La tendance invétérée du Roi de France à s'allier avec les païens contre l'Empereur chrétien contribua peutêtre plus que tout à sauver le Protestantisme en Europe. C'est le péril turc que contraignit Charels Quint à écouter les princes protestantș à la Diète d'Augsbourg en 1530" (27) .

E' difícil, senão impossível, separar as razões acima supostas para o interêsse de Unamuno pelo Corão. A religião e o interêsse por ela estão, na realidade, no âmago de todo o problema. Um grande especialista afirmou, ao referir-se à teoria e função do califado, e mencionando os deveres de interêsse público que Al-Mawardi apontava ao califa:

"Es evidente que estos diez deberes son todos religiosos, pues están referidos directamente a Dios, y equiparados a un caminar por la "senda de Allah". "Muestran con toda claridad la unidad entre religión y política, de lo espiritual y lo temporal, o de los aspectos religiosos e seculares de una vida centrada en Dios y que conduce a Dios. La Teoría del Califado está claramente elaborada sobre la primitiva umimat Al_Islam de Mahoma en Medina. Los

(27). - Stephen Neill, Foi Chrétienne et Autres Croyances, MAME, 1965, pág. 62 , nota 2 . 
historiadores y los autores de "Espejos de Príncipes" subrayan el origen divino de la función califal..." (28).

Até ao início da Idade Moderna, foi o maometismo a religião dominante da maioria peninsular, e daí por diante, a problemática religiosa passa a ser a do catolicismo ou a de definição diante dêste (29), de modo que se pode afirmar, com Tuñon de Lara, que

"Es imposible estudiar la Historia de España sin encontrase con un hecho esencial; un hecho en la conciencia de los hombres $y$ en sus relaciones mutuas, en la estructura social y en las instituciones políticas, en las ideologias que son trasfondo de estados sociales $\mathrm{y}$, a su vez, reactúan sobre ellos: el hecho religioso, en su pluralidad de dimensiones, en sus cristalizaciones diversas y a veces contradictorias que se traducen, también con signo muy diverso, en la compleja marcha de nuestro pueblo a través de siglos de historia" (30).

Não é, porém, êsse o verdadeiro motivo da atenção dedicada por Unamuno ao islamismo e ao Corão na sua obra poética fundamental, - Cancionero. A razão profunda estava na atenção que dedicava o desterrado de Hendaya à própria religião como tal. Qualquer leitor atento de Unamuno sabe disso, e sabe ainda que não era a religião como fenômeno, como simples objeto, mas a própria vivência pessoal religiosa. Juilán Marias dedica um capítulo de seu Miguel de Unamuno ao problema de La Religión en la obra de Unamuno. Destaco alguns trechos dêsse capítulo:

"La obra entera de Unamuno está immersa en un ambiente religioso: cualquier tema acaba en él por mostrar sus raízes reli-

(28). - Erwin T. Rosenthal, El Pensamiento politico en el Islam Medieval, "Revista de Occidente", Madrid, 1967, pág. 53.

(29). - Ver Manuel Turion de Lara, El hecho religioso en España, librerie du Globe, Paris, 1968, pág. 7-8.

(30). - Lara, ob. cit., p. 7. Ver também, sôbre o assunto, R. Altamira, Manual de Historia de España, p. $991^{9}$ §.

Para volver a Unamuno, atente-se para o que disse no Prólogo à obra de Bunge, La Educación: "És indudable que la religión católica, oficial en España, y la que profesan la inmensa mayoría de los españoles - aunque muchos finjan profesarla y otros no tengan conciencia de ella - ha influido y sigue influyenlo en el modo de ser, de vivir, de pensar y de sentir del pueblo español, tanto o más - creo que mucho más - que su lengua, su legislación, su historia, etc. etc. Y si hemos de conocernos y de conocer al pueblo en que vivimos, ¿hemos de desdeñar el estudio de ese elemento?" $E$ acrescenta: "La profunda ignoranciai que en asuntos religiosos nos aqueja es la causa capital de los más de los males - de los que lo sean - que lamentan y combaten los que a la enseñanza de la religión se oponen..." (E III 511-512). 
giosas o culminar en una última referencia a Dios. $Y$ en el fondo nada le interesaba si no podia reducirlo de algún modo a su preocupación permanente" (31).

Poderia demorar-me, neste ponto, a citar autores, dentre os melhores unamunistas, que sublinham essa característica do pensamento e das preocupações de D. Miguel. Melhor será, porém, escutar o próprio Unamuno. No prólogo à edição espanhola do La Agonia del Cristianismo, diz:

\begin{abstract}
"Después de escrito-y publicado en francés este librito, en febrero de este año 1930, creí poder volver a mi España, y me volvi a ella. $Y$ me volví para reanudar aquí, en el seno de la patria, mis campañas civiles, o si se quiere políticas, y mientras me he zahondado en ellas he sentido que me subían mis antiguas, o mejor dicho, mis eternas congojas religiosas, $y$ en el ardor de mis pregones políticos me susurraba la voz aquella que dice: "Y después de esto, ¿para qué todo?, ¿para qué?", Y para aquietar esa voz o a quien me la da, seguía perorando a los creyentes en el progreso $y$ en la civilidad $y$ en la justicia, y para convencerme a mi mismo de sus excelencias" (32).
\end{abstract}

Que Don Miguel de Unamuno estudou o problema religioso em todos os seus aspectos - psicológico, histórico, filosófico, sociológico - é ponto pacífico. Mas também o é o fato de que foi o cristianismo em geral, e a Bíblia, em particular, que dominaram seu espírito. E' verdade, sim, que êle não titubeia em colocar o Corão e os discursos de Buda, e até Dom Quixote, ao lado da Bíblia (33), mas, ao fazê-lo, não os põe no mesmo nível. A Bíblia é, para êle, um livro diferente. Espero demonstrá-lo na tese em preparo sôbre a Presença da Bíblia na Vida, obra e pensamento de D. Miguel de Unamuno. O Corão era apenas o livro sagrado dos maometanos livro que seria absurdo chamar de "sublime" como fêz o autor de certa novela publicada em Paris e que D. Miguel duramente criticou (34). Parece coincidir com a opinião de Unamuno a respeito do Corão a de Ortega Y Gasset, expressa no prólogo à tradução do livro de Ibn Hazm de Córdoba El Collar de la Paloma, em que se refere à civilização árabe como

(31). - J. Moraís, Miguel de Unamuno, EMECE, B. Aires, p. 165.

(32). - A C XVI 456, 457. Note-se o presente: “. . o a quien me la da".

(33). - Cf. U E X 841 .

(34). - Num comentário sôbre a novela "El tiempo del ideal", de Pedro Cesar Dominici, depois de qualificar de "un poco fuerte", "más fuerte aún", "fuertísimo", "gratuito" várias afirmaçōes do autor, escreve: "Pero aún puede pasar esto junto a aquello de llamar "libro sublime" al Corán..." (L H A VIII 117). 


\section{$-368-$ \\ "resequida y petrificada a fuerza de Corán e de desiertos" e afirma que "el Corán apergamina las almas y reseca a un pueblo" (35).}

(35). - J. Ortega y Gasset, Prólogo a El Collar de la Paloma, de Ibn Hazn, trad. de E. García Gómez, in Obras Completas, vol. VII pág. 43-45. Vale a pena transcrever o longo trecho de Ortega y Gasset. Nele, a par dos referidos conceitos sôbre o livro de Maomé, encontra-se maravilhosa e profunda análise do devir histórico do islamismo. Assim escreve:

"La Edad Media europea es, en su realidad, inseparable de la civilización islámica, ya que consiste precisamente en la convivencia, positiva y negativa a la vez, de cristianismo y islamismo sobre un area común impregnada por la cultura greco romana. De aquí que el único punto de vista adecuado sea de indiferencia ante esas dos vertientes de la vida medieval, contemplando su aparente dualidad y discrepancia como unidad y coincidencia, que asumen dos modalidades distintas. Y la razón fuerte de ello es que ambos orbcs - el cristiano y el musulmán - son sólo dos religiones de un mundo geográfico que había sido historicamente informado por la cultura greco romana. La religión islámica misma procede de la cristiana, pero esta procedencia no hubiera podido originarse, a sua vez, si los pueblos europeos y los pueblos árabes no hubiesen penetrado en la área ocupada durante siglos por el Imperio romano. Germanos y arabes eran pueblos periféricos, alojados en los bordes de aquel Imperio, y la história de la Edad Media es la historia de lo que pasa a eses pueblos conforme van pentrando en el mundo imperial romano, instalandose en él y absorbiendo porciones de su cultura gasta ya y necrosificada. La Edad Media, por una de sus caras, es el proceso de una gigantesca recepción: la de la cultura antigua por pueblos de cultura primitiva. $Y$ la génesis cristiana del islamismo no es sino un caso particular de esa recepción, producida por el mismo mecanismo histórico que llevó a los árabes del siglo IX a recibir a Aristoteles y a Hipocrates y a Galeno y a Euclides y a Diofanto y a Tolomeo. Se olvida demasiados que los árabas, antes de Mahoma, llevaban siete siglos rodeados por todas partes de pueblos que estaban más o menos helenizados y que habían vivido hajo la administración romana. No es sólo de Siria de donde sopla sobre los árabes el gran viento de la Antiguedad, sino de Persia, de la Bactriana, y de la India. En cambio, Europa, por su lado norte, se mantuvo libre de influjos grecoromanos y pudo conservar más tiempo intactas las raíces del primitivismo.

Los estádios de esa recepción son, en su comienzo, mui similares. La única diferencia inicial - que es, sin duda, importante - radica en que los árabes recebieron la Antigüedad en su aspecto de Imperio Romano de Oriente, y los europeos en su forma de Império Romano de Occidente. Esto trajo consigo, por ejemplo, que los árabes pudieron tener pronto su Aristóteles, y, en cambio, el Cristianismo, suscitador del Islam, fuese el nestoriano y el de los monofisitas, dos perfiles arcaicos de la fe cristiana. En los estadios siguientes la recepción fué poco a poco tomando caracteres más divergentes, hasta que en el siglo XIII cesa entre los árabes, cuya civilización queda reseca y petrificada a fuerza de Corán e de desiertos. Pues los desiertos, que ciñen por Oriente y Sur el mundo islamico, lanzan sobre él periodicamente oleadas de puritanismo asolador. Los beduinos son sus portadores. La última avenida, bien reciente ha sido la de los Wahhabies del Nechd, que, al concluir la primera guerra mundial, dirigidos por Ibn Sa'ud, cayeron sobre la Arabia de las ciudades de Meca y Medina. Quien quiera ver concretamente cómo el Corán apergamina las almas y reseca a un pueblo, no tiene más que leer las memorias de Tahu Hussein - Le Livre des Jours, 1947 - . El autor, que es ciego, ejerce actualmente el cargo de ministro de Educación en Egipto". 
Neste trabalho, como já disse, tenho a intenção de indicar a presença do Corão no Cancionero (36). Dizendo melhor, só nos interessarão aquêles lugares da obra póstuma do vate sa'mantino em que o próprio autor indica as referências corânicas. Limitar-me-ei a citar os poemas que sofreram evidente influência corânica, mas que não vem acompanhados das respectivas indicações de suras e versículos. São êles os seguintes: c. 71 , c. 255 , c. 555 , c. 942 , c. 960 (cf. C XV p. 849), c. 990 , c. 1169 , c. 1386 , c. 1387, c. 1465. (37).

Os poemas em que existem explícitas citações do Corão são apenas 14. As suras são também só 14. Das 114 suras do Corão, apenas 14 são citadas. Dos seus 6219 versículos (ayat), apenas 26 . Esses números contrastam com os relativos às citações bíblicas. Basta levar em consideração que êssès 14 poemas são parte dos 1755 que a obra contém. Dentro das 14 suras mencionadas acima, há cêrca de 25 citações, incluindo os versículos próximos, desde que citados. Não há têrmo de comparação entre êsses algarismos e os relativos à presença da Bíblia na obra de Unamuno. Só no Cancionero encontrei cêrca de 164 citaç̧̃̃es do Velho Testamento, com predominância do livro do Gênesis (85 citações) e dos Salmos (26 citações) . Do Nôvo Testamento são 463 as citações, com preponderância do 4o Evangelho (82), São Mateus (74), a $2^{\text {a }}$ Carta de Paulo aos Coríntios (48) e o Apocalipse (33). O total das referências bíblicas incluindo as indiretas e subentendidas, é 627. Da Bíblia tôda, minhas buscas, que temo serem incompletas, alcançaram, nas duas dezenas de milhares de páginas das Obras Completas, e algumas ainda não publicadas, a soma aproximada de 4 mil citações bíblicas (38). Pouquíssimos são os livros bíblicos a que Unamuno não faz alguma referência .

Temos que reconhecer que, dêsse ponto de vista, o Corão ocupa lugar quase desprezível na obra de Unamuno.

(36). - Só tenho conhecimento de outro livro, também de poesias, o Rosário de Sonetos Liricos, em que D. Miguel faz citações do Corão. Veja-se o Soneto LXXVIII, Lluvia de Arena. datado de 19 de outubro de 1910, escrito em Salamanca. As referências são: II 66; V 83; IX 32; LXI 18, que D. Miguel escreveu em epigrafe. Ajunto ainda a sura IV verso 43 e o $\mathrm{V}$ verso 6 , onde 0 assunto é também tratado. (O. C. vol. XIII p. 584).

(37). - Todcs êsses poemas mereciam um comentário. Breve referência ao c. 942. Alude à Sura XCVI, denominada Coágulo. Ver a propósito G. Demombynes, Mahoma, págs. 204-205.

(38). - Importa notar também o fato de que êsse enorme acervo de citaçōes bíblicas abrange pràticamente todo o período da vida literária de D. Miguel. As citações do Corão folam feitas apenas num soneto de 1910 e em poucos poemas escritos entre 18 de março e 6 de abril de 1929. 
Páginas atrás, mencionei a significativa circunstância de, na mesma época do exílio em que o nosso autor aludiu algumas vêzes ao Corão, se terem publicado obras importantes acêrca do islamismo. Mas é bom assina'ar que foi precisamente naquele tempo do destêrro de Unamuno que várias e importantes traduções do livro sagrado dos árabes foram feitas. A famosa tradução de Bonelli foi publicada em 1929 (2 $2^{\text {a }}$ edição em 1940). A de Palmer, considerada até o aparecimento da de Arberry, a melhor tradução inglêsa, foi publicada em 1880 e teve sua terceira edição em 1928. (A 2a tinha sido em 1900). A $10^{a}$ edição do Corão de Edouard Montet saiu exatamente em 1929. $E^{\prime}$, aliás, muito provável que tenha sido êste último o texto de que se serviu o poeta na composição dos referidos poemas (39).

São os seguintes os lugares do Cancionero com as respectivas referências corânicas:

(39) . - Não creio que Unamuno se tivesse servido de uma tradução espanhola do Corão. Embora dominasse êle suficientemente o árabe para lê-lo no original, não é necessário crer que o tivesse manuseado, nessa língua quando escreveu o Cancionero. A coincidência do apasecimento, no mesmo ano das composições poéticas, de nova tradução francesa, estando êle na França, corroborada pela correspondência editorial da numeração dos ayat, diversa da por êle usada por maior parte das outras traduções, levam-me a acreditar que foi $o$ texto de Édouard Montet que teve em mãos. A coincidência existe também em J. Vermet e em Savoy. No entanto Vermet só publicou a sua tradução dezessete anos depois da morte de Unamuno (El Corán, traducción y prólogo del D. Juan Vernet, de la Universidad de Barcelona, José Janés Editor, Barcelona, 1953). Quanto à outra, foi ela publicada em Espanhol, sob o nome do conhecido tradutor francês, pela Livraria dos irmãos Garnier, a mesma que também em português editou a obra, estou convencido de que igualmente sôbre a tradução de Savary não do original arábico. Diga-se a propósito que a mesma tradução francesa de $\mathbf{E}$. Savary parece não ter sido exatamente uma obra original, isto é, feita do árabe, apesar do que êle próprio assevera no seu prefácio à edição de 1783 (Le Koran, Librairie Garnier, Paris, 1923, págs. VI-VII). Levanta a suspeita o conhecido e respeitado tradutor Kasimirski ( $L e$ Koran, Eugène Frasquclle, Paris, 1918, pág. XXXIII), o qual afi:ma que Savary "en a fait une évidemment sur la traduction latine de Marracci".

L. Marracci é o autor da primeira boa tradução do livro sagrado dos muçulmanos obra em latim, Alcorani Textus Universus, Padua, 1698, fonte, de acôrdo com o mesmo Kasimirski, da maior parte das traduçōes européias do Corão do século XVII até às mais modernas versões. A primeira tradução latina fôra feita na Espanha em 1143 por ordem do Abade de Cluny, Pedio-o-Venerável. Também na Espanha foi que se empreendeu a primeira tradução do livro de Maomé para uma língua vulgar, o catalāo, por vontade de Pedro IV. Mas tanto essa como a de Assens Cansinos e a da "Biblioteca de Bolsillo" a que alude J. Vernet no prefácio à obra citada, foram feitas indiretamente, através do latim.

Houve, sim, uma edição tilingüe do Corão, em que o espanhol aparecia ao lado do original arábico e do texto latino, realizada pelo professor da Universidade de Salamanca Juan de Segovia no século XV, mas infelizmente está há séculos desaparecida, e duvido que a Inquisição esteja nisso inocente.

Ao levantar a hipótese de o nosso poeta se ter utilizado da tradução francesa, aliás suíça, pelo autor, que era professor da Universidade de Gencbra, não excluo a possibilidade de haver-se servido do texto original, e nesse caso não 


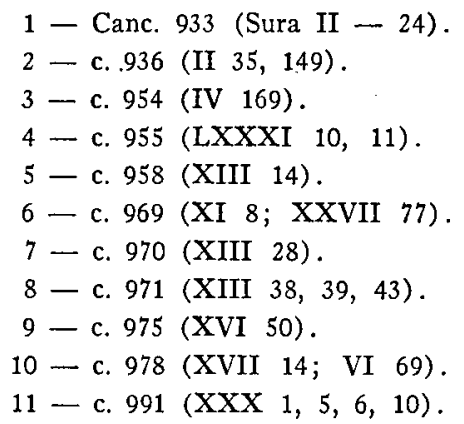

teria sido a de Hinkelmann, a primeira edição do texto corânico em árabe, feita em Hamburgo em 1694, nem a de Molla Osman Ismaël, de São Petersburgo em 1787 e 1803, cujos exemplares são muito raros, mas provàvelmente a de G. Flü-

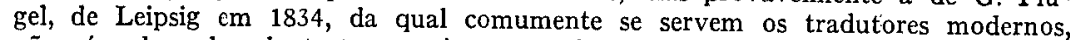
não só pelo valor do texto em si como pela concordância aposta pelo editor ao final do volume.

Nenhum dêsses livros, como nenhuma outra edição do Corão, encontrei na Biblioteca de D. Miguel. Que êle os possuiu, não há dúvida. Mas é sabido que um número muito grande de obras desapareceu das estantes do sábio de Salamanca, tanto de sua casa, pelos expurgos a que foram submetidos pela polícia, como do modesto hotel em que viveu o seu destêrro na fronteira.

Não convém terminar esta nota sem uma referência ao fato de ser para muitos estranho que justamente a Espanha, país islâmico por bitocentos anos, não tenha dado ao mundo uma tradução notável do Corão, cabendo êsse privilégio a outros, principalmente à França, à Itália, à Alcmanha e à Inglaterra.

A mais ortodoxa doutrina maometana acredita que a primeira coisa que Alá criou foi uma pena, e disse-lhe: "Escreve!" Ela perguntou: "Senhor! Que devo escrever? E Alá respondeu:: "Escreve o destinó de tôdas as coisas até o último dia". (A. J. Wensinck, The Muslim Creed, 1932, pág. 108. Apud G. van der Leeuw, Fenomenologia de la Religion, F. C. E., México, 1964, pág. 423, v. 21). Então se escreveu o Corão, antes do tempo existir, que é o que em três lugares do Corão se chama de om el-Kitab, isto é, "mãe do Livro". (Cor. XIII 39; XLIII 4; LII 2-3; LVI 789; LXXX 13-16). Uma crítica liberal, como a do Barão de Vaux, por exemplo, verá nessa expressão corânica em relação com os respectivos contextos, indício da presença da Bíblia, em particular do Pentatêuco, o Livro de que Maomé iria extraindo suas mensagens. (Cf. Baron Carra de Vaux, Les Penseurs de l'Islam, Librairie Paul Geuthner, Paris, 1923, vol. III, pág. 158 ss. Ver tb. L. Massignon, Situation de l'Islam, 1939, pág. 9).

Se o Livro que os discípulos de Maomé escreveram lhes foi ditado pelo Profeta à medida que o Arcanjo Gabriel tho transmitia, é natural que, sendo os discípulos guiados pelo Espírito, como crê a boa tradição, o que veio a ser escrito em árabe como quis Alá (XII 2; XIII 57 ; etc.), é cópia fiel do que se contém na "Mãe do Livro". Daí, a proibição da ala mais conservadora do Islão de se traduzir o Livro Sagrado.

Acredito que essa crença tenha pesado na balança da história da literatura islâmica e mesmo espanhola, ainda que fôsse inconscientemente.

Ignoro se alguém já levantou esta hipótese. Depois da luz que sôbre a presença da cultura arábica na Península lançou o notável crítico Américo Castro, não me parece absurda a idéia que, como disse, ignoro se sou o primeiro a emitir. 


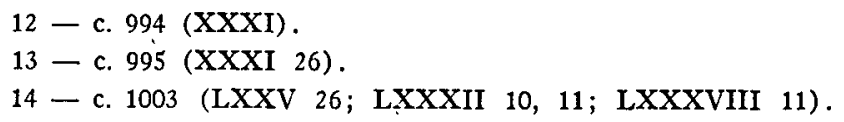

Passemos agora à análise dêsses poemas.

Não está absolutamente, no p'ano dêste trabalho explicar os textos do Corão eleitos, por Unamuno para epígrafes dos poemas acima citados, textos, aliás, por êle nunca transcritos, senão apenas indicados pelas referências numéricas das suras e versículos respectivos. Procurarei, pois, resistir à tentação a que, inevitàvelmente, impele a leitura atenta dos trechos corânicos, não raro ricos em sugestões em seu contexto total, a pedir comentário. Este só se fará quando indispensável à compreensão do próprio texto de D. Miguel.

(Continua) . 